アレルギー疾患の原因となる真菌の種類は数多い，その原因真菌を特定するための診断に，従来の標準化されてい ない真菌アレルゲンエキスを使うことにはさまざまな問題点があり，遺伝子クローニング技術で調製された組換アレルゲ ンを使う方がはるかに有用である.これまでに，70 種以上の真菌アレルゲンがクローニングされており，その中のい くつかはすでに組換体が市販品として入手できる. 市販の組換アレルゲンを用いて IgE 抗体を測定することにより，疾 患ごとで異なる感作のパターンや，真菌アレルゲン間での交差反応性についてさまざまな有用な知見が得られている.

現状では利用できる組換アレルゲンの種類は限られている. 臨床の場でより多くの組換アレルゲンが利用できるよ うに, 真菌アレルゲンの分子生物学的解析をさらに推し進めていく必要がある.

Key words: 真菌アレルギー (fungal allergy), アレルゲン (allergen), 組換アレルゲン (recombinant allergen), IgE 抗体 (IgE antibody), 交差反応性 (cross-reactivity)

\section{はじめに}

真菌は, ダニ, 花粉とならんでアレルギー疾患におけ る主要な原因アレルゲンの一つであると考えられてい る. 真菌に対するI 型アレルギー反応が関与するアレル ギー疾患としては気管支喘息, アレルギー性鼻炎, アト ピー性皮膚炎や，アレルギー性気管支肺アスペルギルス 症 (allergic brochopulmonary aspergillosis, ABPA) な ぞが知られている.これらの疾患において, ABPA を除 いてはその原因となる真菌を特定することは必ずしも容 易ではない.アレルギ一疾患は, 抗原の曝露を受けてそ れに対する感作が成立すれば発症しうるので，ヒトとの 間に何らかの接点がある真菌, すなわちヒトの生活環境 中に生息している多種多様な真菌はどのようなもので も, 感染性, 病原性とは無関係に, ヒトにアレルギーを 発症させる可能性がある.

\section{真菌アレルギーの診断における問題点}

気道アレルギーに関与する真菌は属レベルで 80 以上 あるといわれている1).これらの多種類の真菌のすべて がアレルゲンとして同等に重要であるとは思えないが， わが国で原因アレルゲンを診断するためのアレルゲンエキス で, 医薬品として承認され正式に診療に使うことのでき るものは, Aspergillus, Alternaria, Cladosporium, Penicillium, Candida のわずか 5 種類しかなく, 可能性のある真菌の

別刷請求先 : 安枝 浩 干228-8522 神奈川県相模原市桜台 18-1 国立相模原病院臨床研究センター
すべてにはとても対応できないというのが現状である. 診断用アレルゲンの種類が少ないということに加えて, 真菌アレルギーの診断における問題点として次の 2 点が 挙げられる. すなわち, 真菌アレルゲンは標準化が困難 であるということと，真菌間で広範な交差反応性が見ら れるということである.

真菌のアレルゲンエキスを調製するためには, 培養と いう過程が必須である. 同じ菌株由来であっても, 培地 の選択, 培養時間や温度の相違など, 培養条件によって 産生される抗原成分の組成や濃度は大きく異なるし, 液 体培地の場合には菌体成分を用いるのか濾液成分を用い るのかによっても構成成分の組成は大幅に異なってく $る^{2)}$.このために, 真菌アレルゲンを標準化するという 作業は, 各種の花粉アレルゲンやダニアレルゲン以上に 困難である. 実際, 欧米ではさまざまなアレルゲンの標 準化が実施され，標準化アレルゲンエキスが日常診療に 利用されているが, 真菌に関してはこれまでのところ標 準化されたアレルゲンは市販されていない.

真菌間での広範な交差反応性に関与するのは，1 つは pan-allergen といわれる進化の過程で高度に保存された タンパク質アレルゲンである. 分類学的に遠くかけ離れ た種の間においても分子の構造的類似性が高いために互 いに強く交差反応する ${ }^{3,4)}$. pan-allergen が関与する代表 的な疾患として, 花粉症やラテックスアレルギーに合併 した口腔内アレルギー症候群 (oral allergy syndrome, OAS）がよく知られているが ${ }^{5}$, 真菌の場合にも, MnSOD (Manganese superoxide dismutase), cyclophilin, enolase などが pan-allergen として働き, 異なった真菌種の間 
での交差反応に関与する ${ }^{6-8)}$.もう1つは, cross-reactive carbohydrate determinant, CCDといわれているマンナ ンやガラクトマンナンなどの多糖体アレルゲンである ${ }^{2,9)}$. 多糖体アレルゲンは $\operatorname{IgE}$ 抗体との親和性が低いた めに臨床的にはほとんど意味を持たないと考えられてい るが，少なくともin vitroにおける $\operatorname{IgE}$ 抗体の測定系に は大きく影響してくる.

従来の標準化されていない真菌アレルゲンエキスを使 う限りはこのような問題は絶えずつきまとう.この問題 を解決するにはさまざまな成分の雑多な混合物であるア レルゲンエキスではなく, 単一のアレルゲン精製標品, あるいはそれを適切にブレンドしたものを使用する必要 がある ${ }^{10)}$. このような診断に用いる精製アレルゲンを真 菌抽出液から調製するというのは, 精製に要する時間と 労力を考えると非現実的であり，アレルゲンの遺伝子を クローニングしてその組換体を調製するという方法をと ることが必須になる.

\section{真菌アレルゲンのクローニング}

真菌に限らず同定, 精製されたアレルゲン，あるいは クローニングされたアレルゲンはWHO/IUIS (International Union of Immunological Societies) のアレルゲ ン命名委員会において一括して管理され，ここに登録 されたアレルゲンには統一的な名称が付けられてい る ${ }^{11)}$.この命名法ではアレルゲン名をその学名の属名 3 文字と種小名 1 文字で表し, 登録された順番にアラビア 数字で番号を付ける. したがって, Aspergillus fumigatus のアレルゲンはAsp f 1, Asp f 2 ‥となり, Malassezia furfurのアレルゲンは Mal f 1, Mal f 2 ‥となる.

アレルゲンの遺伝子をクローニングするためにさまざ まな技術が応用されているが，その方法は大きく 2 つに 分けられる.1つは，まずアレルゲンタンパク質を単離, あるいは同定して，そのタンパク質のアミノ酸配列情報 をもとに PCR を利用してクローニングするという方法 であり，もう1つは，最初からcDNA expression library
を構築して, 患者血清中の $\operatorname{IgE}$ 抗体をプローブにしてク ローニングするという方法である. 後者の方法は前者 とは異なり, 適切な発現系を構築すれば一つのライブラ リーから多種類のアレルゲンを一挙にクローニングする ことができる.しかしこの方法では天然のアレルゲンの 単離，同定を全く行わないので，組換体を調製したとき にそれが天然のものと同等の活性を持っているのかどう かの直接的な確認をすることができないという問題点が ある. 我々が $M$. furfurの一連のアレルゲンをクローニ ングしたときは前者の方法で行い ${ }^{12,13)}$, 最近, 最も精力 的に解析が進められている A. fumigatus のアレルゲンは 主に後者の方法でクローニングされている ${ }^{14,15)}$.

2003 年 10 月現在, 遺伝子がクローニングされた真菌 由来のアレルゲン約 70 種類がアレルゲン命名委員会の リストに登録されている (http://www.allergen.org/参 照).また, 委員会のリストには登録されていないアレル ゲンも数多くある. 代表的なアレルゲンを Table 1 に示 した. 表中の PMP20 は, 細胞質小器官であるペリオキ シゾームの膜関連タンパク質で, Candida boidinii で最初 に同定されたものである ${ }^{16)}$. 表から明らかなように，同 じグループのタンパク質が複数の菌種においてアレルゲ ンになっていることが多い.これらのタンパク質が構造 的類似性の高いものであれば，いわゆる pan-allergen と なり, 分類学的にはかけ離れた菌種間においても強い交 差反応性を示す.

\section{市販の組換アレルゲン}

いつたん遺伝子がクローニングされ配列が明らかにな ると，その組換体を大規模に発現，調製することは，現在 の遺伝子工学の技術をもってすればそれほど困難なこと ではなく，いくつかの組換アレルゲンはすでに市販され ている. M. furfurの Mal f 2 (PMP 20), MF3 (MnSOD), Mal f 6 (cyclophilin), Candida albicans $の$ MnSOD, cyclophilin は夕カラバイオから, A. fumigatusの Asp f 1 (mitogilin), Asp f 2, Asp f 3 (PMP 20), Asp f 4, Asp

Table 1. Some cDNA-cloned fungal allergens

\begin{tabular}{|c|c|c|c|c|}
\hline \multirow{2}{*}{$\frac{\text { Species }}{\text { Aspergillus fumigatus }}$} & \multicolumn{4}{|c|}{ Allergen } \\
\hline & $\begin{array}{l}\text { Asp f } 1 \\
\text { (mitogilin) }\end{array}$ & $\begin{array}{l}\text { Asp f } 3 \\
(\mathrm{PMP} 20)\end{array}$ & $\begin{array}{l}\text { Asp f } 6 \\
(\mathrm{MnSOD})\end{array}$ & $\begin{array}{l}\text { Asp f } 11 \\
\text { (cyclophilin) }\end{array}$ \\
\hline Alternaria alternata & Alt a 1 & $\begin{array}{l}\text { Alt a } 11 \\
\text { (enolase) }\end{array}$ & & \\
\hline Penicillium citrinum & $\begin{array}{l}\text { Pen c } 3 \\
\text { (PMP20) }\end{array}$ & $\begin{array}{l}\text { Pen c } 13 \\
\text { (serine protease) }\end{array}$ & & \\
\hline Cladosporium herbarum & Cla h 1 & $\begin{array}{l}\text { Cla h } 6 \\
\text { (enolase) }\end{array}$ & & \\
\hline Malassezia furfur & $\begin{array}{l}\text { Mal f } 2 \\
(\mathrm{PMP} 20)\end{array}$ & $\begin{array}{l}\text { MF3 } \\
\text { (MnSOD) }\end{array}$ & $\begin{array}{l}\text { Mal f } 4 \\
(\mathrm{MMD})\end{array}$ & $\begin{array}{l}\text { Mal f } 6 \\
\text { (cyclophilin) }\end{array}$ \\
\hline Trichophyton tonsurans & Tri t 1 & $\begin{array}{l}\text { Tri } 4 \\
\text { (serine protease) }\end{array}$ & & \\
\hline
\end{tabular}

PMP20: peroxisomal membrane protein 20

MnSOD: Manganese superoxide dismutase

MMD: mitochondrial malate dehydrogenase 
f 6 (MnSOD) はファルマシアから, Alternaria alternata Alt a 1, Alt a 11 (enolase) はオーストリアのBioMayか ら入手できる. なお，ファルマシアの Asp f 1〜Asp f 6 は組換タンパク質そのものでなく IgE 抗体測定用の ImmunoCap として市販されている.

Fig. 1 に $M$. furfur のMal f 2, MF3, Mal f 6 につい て, 菌体抽出液から精製した天然体と組換体市販品の SDS-PAGE におけるband の比較を示した. 組換体と天 然体のバンドは完全に一致しており, また対応する菌体 抽出液中のバンドとも一致して, 組換体の見かけ上の分 子量が天然体と同じであることを示している.しかし， 組換体の分子量が天然体と同じであったとしても，ある いはアミノ酸配列が同じであったとしても，組換体のア レルゲン活性が天然のものと同じであるという保証はど こにもない. IgE 抗体はアレルゲン分子の 3 次元構造を 主要なエピトープとして認識するので, 発現されたタン パク質が天然のものと同じ立体構造をとっていなければ そのアレルゲンの活性は大幅に低くなる. すなわち, ど のような系, あるいは方法で組換体を発現させるのかと いうことが非常に重要になってくる. Fig. 2 にこれらの

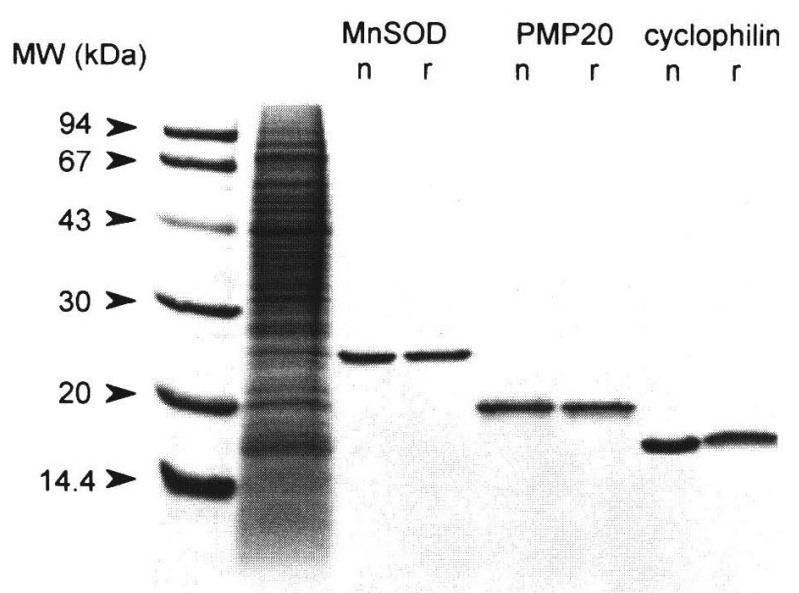

Fig. 1. SDS-PAGE analysis of natural ( $\mathrm{n}$ ) and recombinant ( $\mathrm{r}$ ) forms of Malassezia furfur allergens.
アレルゲンについて, 菌体抽出液から精製した天然体と 組換体に対するアトピ一性皮膚炎患者血清中 $\operatorname{IgE}$ 抗体 価の相関を示した. Mal f 2, MF3においては天然体と 組換体に対する抗体価がほぼ 1：1で対応していて, 両 者の活性に差が見られないが，Malｆ６においては天然 体のみに $\operatorname{IgE}$ 抗体が陽性で組換体には反応しない血清 が全体の約 $1 / 3$ にみられ，組換体が $100 \%$ その活性を保 持しているわけではないということを示している. しか しながら，これらのM. furfurのアレルゲンのように天 然の精製標品が得られていることはむしろ例外で, 多く のアレルゲンは天然体を同定することなしにクローニン グして組換体が調製されているので，組換体のアレルゲ ン活性について十分に評価されていないのが現状であ る.

\section{組換アレルゲンの診断への利用}

\section{ABPA の鑑別診断}

いくつかの臨床的所見と血清学的な所見を組み合わせ たABPAの診断基準が 1977 年に設けられているが17), ABPAの診断に関しては今日でもさまざまな議論が絶 えない. Crameri らは, A. fumigatus のいくつかの組換ア レルゲンに対する IgE 抗体を測定するだけで ABPAの鑑 別ができるという, 新しい診断法を提唱している ${ }^{15,18)}$. Table 2 にその具体的なデー夕を示した. ABPA 54 例 之, 主にAspergillusに感作された喘息患者である非 ABPA 35 例について Asp f 1 から Asp f 6 までの 4 種類の組換 アレルゲンに対する IgE 抗体を測定すると, Asp f 1 と Asp f 3 に対しては両群ともに陽性例が見られる.しか し, Asp f 4 とAsp f 6 に対しては非 ABPA群全例が陰 性であるのに対して, ABPA 群は陽性率がAsp f 4 に対 しては78\%,Asp f 6 に対しては56\%で，しかも全例が 少なくともどちらか一方に陽性である(Table 2). した がって, Asp f 4 と Asp f 6 に対するIgE抗体を測定して, どちらか一方に陽性であればABPA と診断できる，とい うことになる. 何故 Asp f 4 と Asp f 6 に対する IgE 抗体 はABPA 患者だけが陽性になり喘息患者は陽性になら
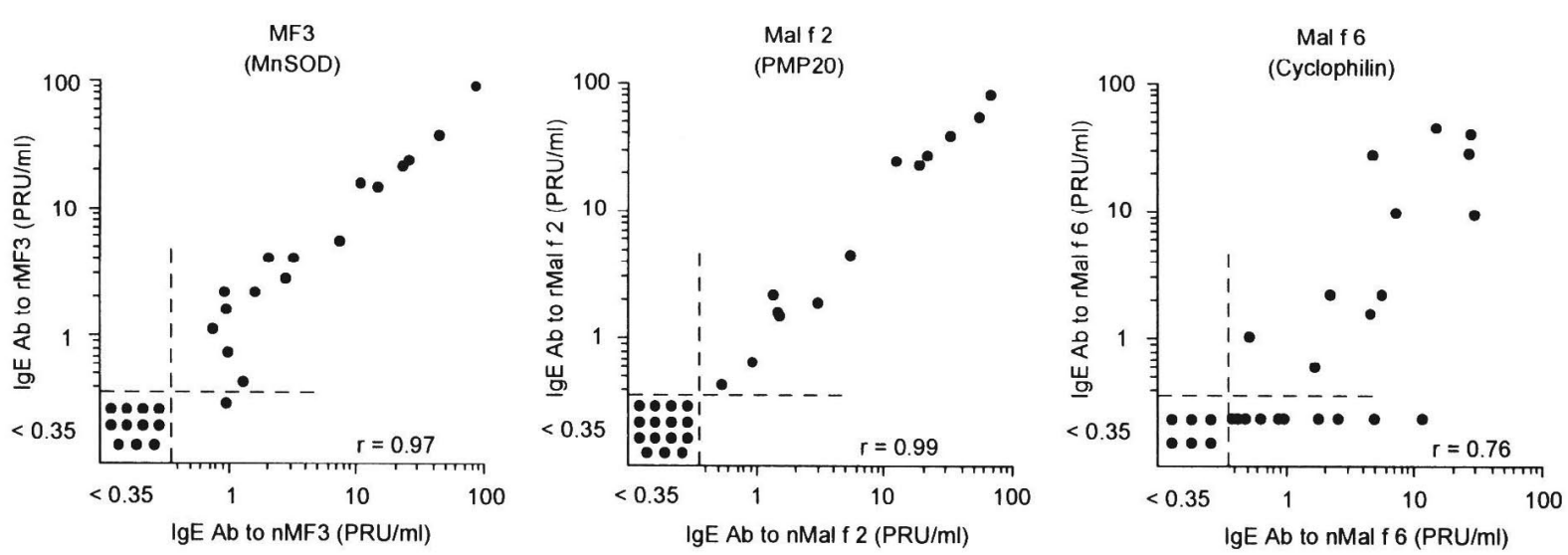

Fig. 2. Comparison of allergenic activities of natural and recombinant forms of Malassezia furfur allergens. IgE antibody levels to natural and recombinant forms of MF3, Mal f 2 and Mal f 6 in sera from 27 Malassezia furfur-sensitized patients with atopic dermatitis were measured by RAST. 
Table 2. Sensitization of asthmatic patients with and without ABPA to different recombinant $A$. fumigatus allergens ${ }^{15)}$

\begin{tabular}{lcccc}
\hline \multirow{2}{*}{ Patient } & \multicolumn{3}{c}{ IgE antibody (ELISA units/m $l)$} \\
\cline { 2 - 5 } & rAsp f 1 & rAsp f 3 & rAsp f 4 & rAsp f 6 \\
\hline Asthma with ABPA & $173 \pm 510$ & $412 \pm 454$ & $47 \pm 67$ & $54 \pm 110$ \\
$(n=54)$ & $45 / 54(83 \%)$ & $51 / 54(94 \%)$ & $42 / 54(78 \%)$ & $30 / 54(56 \%)$ \\
Asthma without ABPA & $29 \pm 53$ & $110 \pm 238$ & $<5$ & $<5$ \\
$(n=35)$ & $16 / 35(46 \%)$ & $17 / 35(46 \%)$ & $0 / 35(0 \%)$ & $0 / 35(0 \%)$ \\
Healthy controls & $<5$ & $<5$ & $<5$ & $<5$ \\
$(n=20)$ & $0 / 20(0 \%)$ & $0 / 20(0 \%)$ & $0 / 20(0 \%)$ & $0 / 20(0 \%)$ \\
\hline
\end{tabular}

The upper row represents the mean value $\pm \mathrm{SD}$ of IgE binding to the allergen, and the lower row the number and percentage of individuals sensitized to the allergen for each group of subjects.

ないのかという問いに対しては, 両者は非分泌性の細胞 内タンパク質で, 遊離の形で空中アレルゲンとして環境 中には存在しないために，喘息患者が曝露される機会は ない. ABPA患者においては, 菌が気道に colonizeしてそ れが生体側の貪食などの防御メカニズムで破壊されたと きには, 非分泌性の細胞内タンパク質に対しても曝露さ れるために，それに対する免疫応答が起こり感作され る, というように説明している. しかし, Asp f 3 (PMP20) はペルオキシゾームの膜関連タンパク質 ${ }^{16)}$ で非分泌性 であるし, Asp f 1 も菌が発芽するときにしか分泌され ず，環境中からはほとんど検出されないということが明 らかにされている ${ }^{19)}$. したがって, Crameri の説明は当 を得ていないのかもわからないが，米国の ABPA 患者を 対象とした調査でも Table 2 と同様の成績が得られてお $り^{20)}$ ，理由はともかく事実として IgE 抗体の測定だけで ABPAの鑑別診断ができればそれは画期的なことであ る.それでは，わが国の患者ではごうなのかを見るため に，相模原の症例を対象に予備的な検討をしてみた. Asp f 4 とAsp f 6 に対しては, 喘息患者は 4 例と少ないが 全例が陰性で, ABPA は 12 例のうち 10 例が少なくとも どちらか一方に対しては陽性であり (Fig. 3), Crameri の主張とほぼ一致している.しかし, Malasseziaに対す る $\operatorname{IgE}$ 抗体が高値のアトピー性皮膚炎患者 ${ }^{21)}$ も, Asp f 6 に対する $\operatorname{IgE}$ 抗体は ABPA 患者と同等，あるいはそれ 以上に高值である (Fig. 3). 気道症状のないアトピー性 皮膚炎患者を ABPA と診断することはあり得ないが, 気管支喘息にアトピー性皮膚炎を合併した患者でも Malassezia に対する IgE 抗体が高值の例は同様に, 多く がAsp f 6 に対しても IgE 抗体が高值である.これらの 結果は, Crameri の主張を全面的に支持できるわけでは なく，アトピー性皮膚炎合併例に注意を払う必要はある が, 組換アレルゲンに対する IgE 抗体の測定だけで, ABPA を鑑別診断できる可能性のあることを示してい る.さらに症例を増やして詳細に解析をする必要がある.

\section{Aspergillus とMalassezia の間での交差反応性}

Fig. 3 に示したように, Malasseziaに対する $\operatorname{IgE}$ 抗体 が高值のアトピー性皮膚炎患者は，特にAsp f 6 に対す る IgE 抗体が高值である. そこで, Asp f 6 と同じMnSOD

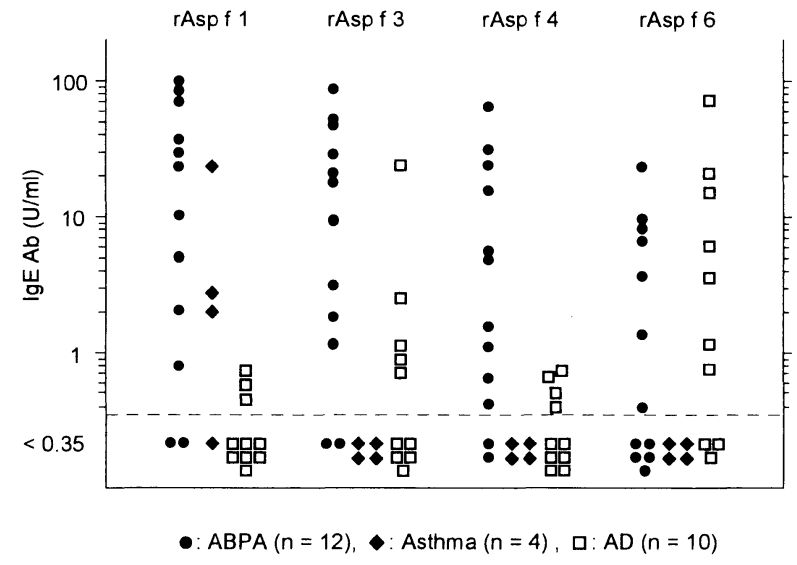

Fig. 3. Comparison of IgE antibody levels to $r A s p f 1, r A s p f 3$, rAsp $\mathrm{f} 4$ and rAsp $\mathrm{f} 6$ in sera from patients with ABPA ( $n$ $=12)$, asthma $(n=4)$ and atopic dermatitis $(n=10)$.

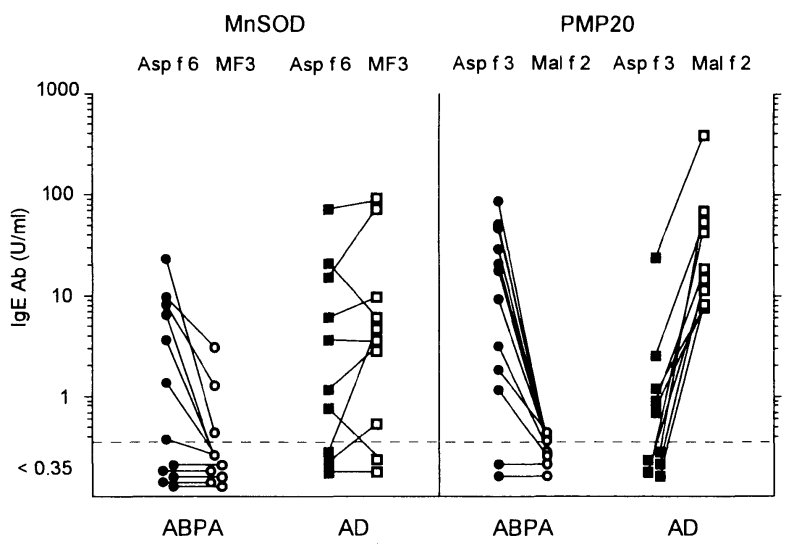

Fig. 4. Comparison of IgE antibody levels to MnSODs and PMP20s from Aspergillus fumigatus and Malassezia furfur in sera from patients with ABPA and atopic dermatitis.

であるMalassezia の MF3，およびAsp f 3 と同じPMP20 である Mal f 2 に対する IgE 抗体を測定して, ABPA 患 者とアトピー性皮膚炎患者のAspergillus とMalasseziaの 対応するアレルゲン間での抗体価を比較した (Fig. 4). MnSOD に対しては，アトピー性皮膚炎患者は多くが Asp f 6 と MF3 に対して同等の抗体価を示し, ABPA患 者も Asp f 6 陽性例の半数は MF3 にも陽性である. 一 


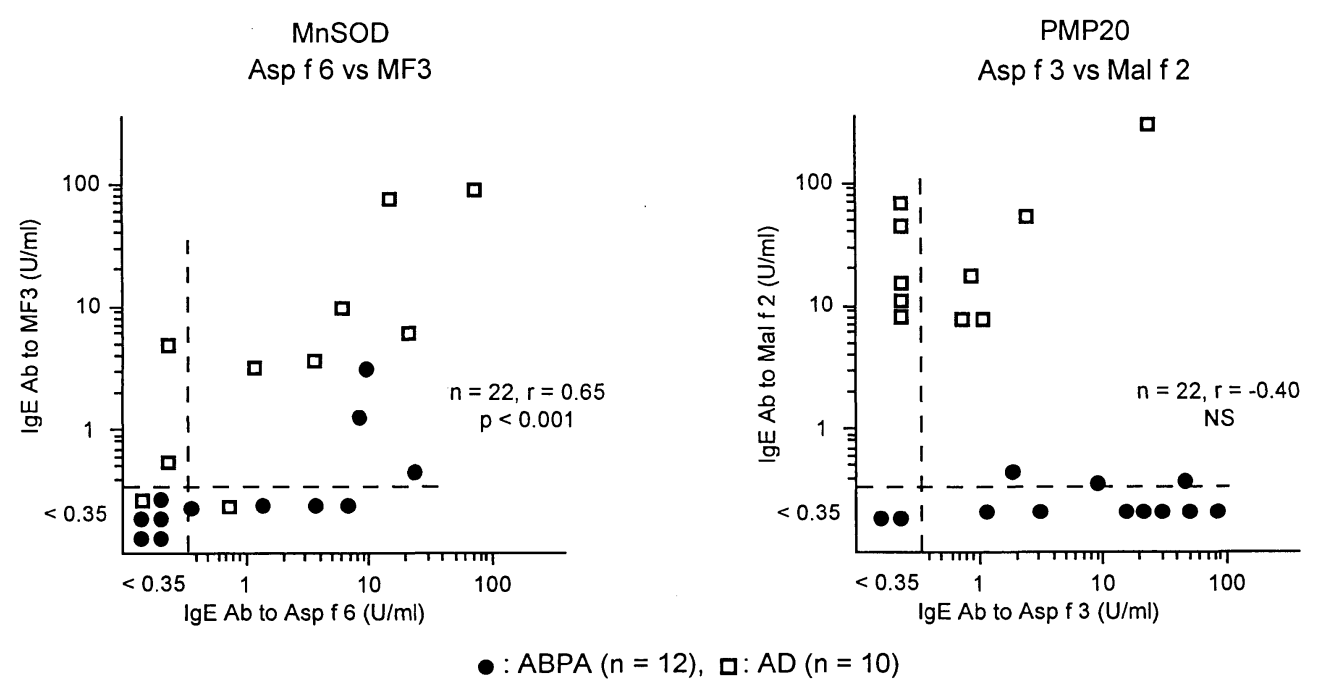

Fig. 5. Correlation between IgE antibody levels to Asp $f 6$ and MF3 (left) and those to Asp $f 3$ and Mal $f 2$ (right) in sera from patients with ABPA and atopic dermatitis.

方, PMP20 に対しては, ABPA 患者は Mal f 2 にはほと んごが陰性で, 逆にアトピー性皮膚炎患者はAsp f 3 に 対しては Mal f 2 に比べて大幅に低值である. Fig. 4 の デー夕を書き改めて, Aspergillus とMalasseziaに対する抗 体価の相関を見ると（Fig. 5), PMP20の場合はABPA 群とアトピー性皮膚炎群で大きな乘離が見られ全体では 全く相関しないが, MnSOD の場合には両群の抗体価に それほど大きな違いはなく, 両群全体で有意に相関する. これらの結果は, Aspergillus とMalassezia の間で MnSOD は非常に強く交差反応し, 逆に PMP20 の交差反応性は きわめて弱い，ということを強く示唆している.この交 差反応性の違いは MnSOD と PMP20アミノ酸配列一致 率の程度の違いによる. Asp f 6 と MF3 の間, Asp f 3 と Mal f 2 の間のアミノ酸配列の一致率はそれぞれ, 62.7\%，37.6\%である. 一致率が高い, すなわち, 分子の 構造的類似性が高いものほど強く交差反応する. MnSOD のような pan-allergen に感作されていれば, 少なくとも IgE 抗体の測定系においては感作された菌種の MnSOD だけでなく,さまざまな菌種の MnSOD, さらにはヒト の MnSOD とも反応し得る22). しかし，このような panallergen による交差反応が臨床的にどれだけの意味があ るのかということについての解明は今後の課題である.

真菌アレルギーの診断において, 組換アレルゲンは従 来のアレルゲンエキスよりもはるかに有用であり, 組換 アレルゲンを用いることによりさまざまな新知見を得る ことができる. 現状では利用できるアレルゲンの種類は 限られているため, 真菌アレルゲンの分子生物学的解析 をさらに推し進めて, その成果を臨床の場に還元してい くことが望まれる.

\section{引用文献}

1) Bush RK, Portnoy JM: The role and abatement of fungal allergens in allergic diseases. $J$ Allergy Clin
Immunol 107: S430-S440, 2001.

2) Nissen D, Petersen LJ, Esch R, Svejgaard E, Skov PS, Poulsen LK, Nolte H: IgE sensitization to cellular and culture filtrates of fungal extracts in patients with atopic dermatitis. Annal Allergy Asthma Immunol 81: 247-255, 1998.

3) Breiteneder H, Ebner C: Molecular and biochemical classification of plant-derived food allergens. J Allergy Clin Immunol 1006: 27-36, 2000.

4) Reese G, Ayuso R, Lehrer SB: Tropomyosin: an invertebrate pan-allergen. Int Arch Allergy Immunol 119: 247-258, 1999.

5) Yagami $T$ : Allergies to cross-reactive plant proteins. Latex-fruits syndrome is comparable with pollen-food allergy syndrome. Int Arch Allergy Immunol 128: 271 $-279,2002$.

6) Fluckiger S, Scapozza S, Mayer C, Blaser K, Folkers $\mathrm{G}$, Crameri R: Immunological and structural analysis of IgE-mediated cross-reactivity between Manganese superoxide dismutases. Int Arch Allergy Immunol 128: 292-303, 2002.

7) Fluckiger S, Fijten H, Whitley H, Blaser K, Crameri $\mathrm{R}$ : Cyclophilins, a new family of cross-reactive allergens. Eur J Immunol 32: 10-17, 2002.

8) Breitenbach $M$, Simon B, Probst G, Oberkofler H, Ferreira F, Briza P, Aschatz G, Unger A, Ebner C, Kraft D, Hirschwehr R: Enolases are highly conserved fungal allergens. Int Arch Allergy Immunol 113: 114117, 1997.

9) Akiyama K, Shida T, Yasueda H, Saito A, Hasegawa M, Maeda Y, Takesako K, Yamaguchi H, Kato H: Assay for detecting IgE and IgG antibodies against Candida albicans cell-wall mannan. Allergy 53: 173-179, 1998.

10) Valenta R, Lidholm J, Niederberger V, Hayek B, Kraft D, Gronlund H: The recombinant allergen-based concept of component-resolved diagnosis and immuno- 
therapy (CRD and CRIT). Clin Exp Allergy 29: 896904, 1999.

11) King TP, Hoffman D, Lowenstein $H$, Marsh DG, PlattsMills TAE, Thomas W: Allergen nomenclature. Bull WHO 72: 797-806, 1994.

12) Yasueda $H$, Hashida-Okado $T$, Saito A, Uchida $K$, Kuroda M, Onishi Y, Takahashi K, Yamaguchi $\mathrm{H}$, Takesako K, Akiyama K: Identification and cloning of two novel allergens from the lipophilic yeast, Malassezia furfur. Biochem Biophys Res Commun 248: 240-244, 1998.

13) Onishi $Y$, Kuroda $M$, Yasueda $H$, Saito A, SonoKoyama E, Tunasawa S, Hashida-Okado T, Yagihara $\mathrm{T}$, Uchida K, Yamaguchi H, Akiyama K, Kato I, Takesako K: Two-dimensional electrophoresis of Malassezia allergens for atopic dermatitis and isolation of $\mathrm{Mal}$ f 4 homologs with mitochondrial malate dehydrogenase. Eur J Biochem 261: 148-154, 1999.

14) Crameri R, Blaser K: Cloning allergens from Aspergillus fumigatus: The filamentous phage approach. Int Arch Allergy Immunol 107: 460-461, 1995.

15) Crameri R: Recombinant Aspergillus fumigatus allergens: Form the nucleotide sequence to clinical applications. Int Arch Allergy Immunol 115: 99-114, 1998.

16) Garrard LJ, Goodman JM: Two genes encode the major membrane-associated protein of methanol-induced peroxisomes from Candida boidinii. J Biol Chem 264: 13929-13937, 1989.

17) Rosenberg M, Patterson R, Mintzer R, Cooper BJ, Roberts M, Harris KE: Clinical and immunologic criteria for the diagnosis of allergic bronchopulmonary aspergillosis. Ann Intern Med 86: 405-414, 1977.

18) Crameri R, Hemmann S, Ismail C, Menz G, Blaser K: Disease-specific recombinant allergens for the diagnosis of allergic bronchopulmonary aspergillisis. Int Immunol 10: 1211-1216, 1998.

19) Sporik RB, Arruda LK, Woodfolk J, Chapman MD: Environmental exposure to Aspergillus fumigatus allergen $($ Asp $f$ I). Clin Exp Allergy 23: 326-331, 1993.

20) Kurup VP, Banerjee B, Hemmann S, Greenberger PA, Blaser K, Crameri R: Selected recombinant Aspergillus fumigatus allergens bind specifically to $\operatorname{IgE}$ in $\mathrm{ABPA}$. Clin Exp Allergy 30: 988-993, 2000.

21）浅古佳子, 齋藤明美, 安枝 浩, 川口博史, 秋山一男, 遠 藤政博, 大西佳美, 竹迫一任: Candida albicans, Malassezia furfurの精製抗原に対するアトピ一性皮膚炎患者の反応 性に関する検討. アレルギー 51: 615-621，2002.

22) Crameri R, Faith A, Hemman S, Jaussi R, Ismail C, Menz G, Blaser K: Humoral and cell-mediated autoimmunity in allergy to Aspergillus fumigatus. J Exp Med 184: 265-270, 1996

\title{
Molecular Cloning of Fungal Allergens and Clinical Applications of Recombinant Allergens in Fungal Allergy
}

\author{
Hiroshi Yasueda, Yasuo Takeuchi \\ Clinical Research Center for Allergy and Rheumatology, National Sagamihara Hospital, \\ 18-1 Sakuradai, Sagamihara, Kanagawa 228-8522, Japan
}

A large number of fungi are associated with allergic disorders. There are many problems in using non-standardized fungal extracts for diagnosis of fungal allergy. These problems can be solved by using genetically engineered recombinant allergens. At present, more than 70 fungal allergens have been cloned and sequenced, and the recombinant forms of several of these are commercially available.

Measurement of $\operatorname{IgE}$ antibodies to these commercially available recombinant allergens could provide the tools useful for characterizing the differential sensitization pattern in relation to a paticular disease and the allergenic cross-reactivity among fungi.

Only a limited number of recombinant allergens are available at present, thus further studies on the molecular biology of fungal allergens are needed so that more recombinant allergens can be used in the clinical field. 